\title{
PARTY ARENAS IN SLOVENIA AND SLOVAKIA
}

Uroš PINTERIČ, Viera ŽÚBOROVÁ

Faculty of Social Sciences, Trnava, Slovakia

UDK: 329.055(497.4:437.6)

$316.776(497.4): 329$

$316.776(437.6): 329$

Izvorni znanstveni rad

Primlieno: 18. 12. 2012.

This article is based on the comparative research of media-indicated party positions in the so-called "left-right continuum" versus the position of political parties on this continuum, as determined by their programmes. The authors argue that media usage of left and right positioning has, over time, caused detachment of left/right attributes from political programmes. The study tries to show that in Slovenia and Slovakia there is a difference between "media" labels of the party positions and the latter's positioning on the basis of their programmes.

Keywords: left-wing, right-wing, political parties, Slovenia, Slovakia, mass media, political programmes

Uroš Pinterič, Faculty of Social Sciences, University of SS. Cyril and Methodius in Trnava, Bučianska 4/A, 91701 Trnava, Slovakia.

E-mail: uros.pinteric@gmail.com

In modern and stable democracies, the development of political ideologies and political parties has been permanently linked. The left-right axis was, and still is one of the main tools of communication used by political parties that adapted this ideological orientation to maximize their potential electoral preferences. Politics used these ideologies to characterize the position of the political parties. In general, two views where formed in particular from the dimensional notion (notions) and the occupation of this (these) by political parties: on one hand, the existence of an adversarial character of parties which leads to a "superposition of dualism" (Duverger, 1967, in Daalder, 1992, 
DRUŠ. ISTRAŽ. ZAGREB GOD. 23 (2014), BR. 2, STR. $349-368$

PINTERIČ, U. ŽÚBOROVÁ $V$ : PARTY ARENAS... p. 275), and on the other hand, the quantum of the ideological standards tabloid in a one-dimensional framework (Sartori, 2005, p. 337).

Bobbio (1995) observes that the traditional positions of the political parties on the left-right axis fluctuate. In the past, they were very stable and balanced with "more or less equal possibility of holding the allegiance of large sections of society and therefore attaining power" (Bobbio, 1995). Political subjects used the left-right axis to describe the permanent ideological conflict between equality and inequality (Bobbio, 1995). Nowadays, the borders between left and right have started to become volatile. With the rise of new societal relations, the traditional distinction of the left-right axis started to change as well.

Comparative analyses show that the left-right spectrum in Western democracies differs in many ways from the party positioning in Central and Eastern Europe (CEE). The self-positioning of parties at the left-right spectrum in Western democracies is generally based on relation towards the individual policy issues (Pop-Eleches \& Tucker, 2010, p. 1), while in CEE countries, parties understand it as political positioning, often based on economic values.

To understand the development of the positioning of political parties along the left-right axis in the CEE countries, some difficulties, such as the historical and modernization approach must be taken into account. The communist era blurred or even removed the cleavages (see Fink Hafner, 2001) between the left and right values. Since the democratization, voters in CEE have to differentiate between "left and right" again. The new point of differentiation was often connected to the pro/anti-communist perspective. Western scientists connected this specific situation with the stabilisation of the party system in the CEE and to the phenomenon of the "missing middle class" in the CEE (Večerník, 1998).

As Tavits and Letki (2009) demonstrated, the dual transition in post-communist countries often led left-wing political parties to copy economic and reform models from the right-wing parties in order to differentiate from the communist past. Left wing parties tried to improve their reputation and to hold their stable electorate. On the other hand, right-wing political parties, especially when composing government, were not able to fully adapt the logic of traditional right-wing parties, particularly in the economic dimension. Mainly due to the fact that they were not able to rely on stable electoral support, as could their left-wing counterparts (Yordanova \& Zhelyazkov, 2011, p. 2).

The second factor that influenced the non-adaptation of the left-right axis (in a traditional sense) in many CEE post- 
DRUŠ. ISTRAŽ. ZAGREB GOD. 23 (2014), BR. 2 STR. 349-368

PINTERIČ, U. ŽÚBOROVÁ, $V$.: ZUUBOROVA, V.: -communist countries is the party system itself. The voters sometimes identify themselves more with the personalities rather than policies and party ideologies. One of the reasons could be the specific historical context of the countries in post-communist Europe (Wyman, White, Milier, \& Heywood, 1998). On the other hand, political parties were not able to develop stable and effective structures due to a rather short transition period between communism and democracy (Wyman et al., 1998; see also Lewis, 2007). At the same time, political parties tried to win the greatest share of votes by proclaiming being centrist by covering all options that were not considered extreme (on this positioning see Bobbio, 1995). They preferred electoral victory over stable development of ideological position and strong members' base.

One could also observe that the mentioned elements of party development in CEE countries are connected to the socalled media or marketing parties (Wojtas, 2006). The organizational structure and the position of such CEE parties in the CEE countries tend to be on a different level than that in the Western countries. In opposition to Western democracies, the CEE countries present (Kitschelt, 1992; Kopecký, 1995; Mair, 1996; Lewis, 1994):

- A stable existence of an anti-party culture;

- Re-grounding of voters electorate, as the main factor of post-communist society;

- The trend to organize and build political parties from elites of the transition periods, rather than those "external", based on social movements;

- The rise of the impact and importance of the media in the common interaction;

- The rise and the need of political parties to occupy the state.

Simultaneously, one shall not miss the observation that ideological meaning of left and right is almost non-existent, despite being used on a daily basis (this case is strongly developed in Slovenia). Research in this field shows that respondents are able to intuitively recognise elements of left and right ideological poles, but they are not willing to clearly mark them as such (see Koprivnik, 2001, p. 146). Therefore, the article analyses, on the study of two countries, the differences between left-right perception in the mass media/public and the political programmes of the major political parties, based on one of the most known studies of left-right polarization by Bobbio (1995). 
Our basic assumption is that today's categorization of political parties as presented in the mass media or understood as "common sense" categorization is over-simplified and made on the basis of partial information or past ideological perceptions. On the other hand, we assume that the analysis of party programmes shows that political parties in Slovenia as well as in Slovakia are much more centre oriented or in the strange position of being politically on the left side and economically on the right. At the same time, we expect that Slovak parties will be politically more right oriented than Slovenian parties, while in the economic sense there will be no significant difference.

The question is, to what extent is the left-right axis relevant to the positioning of political parties in the economic and political dimension, in the case of a cross-national analysis of the party system in the Republics of Slovakia and Slovenia?

\section{NORBERTO BOBBIO'S INTERPRETATION}

Bobbio (1995) researched the Italian party arena before the parliamentarian election. His work is interesting especially from the perspective, that, within the same study, he offers different models of how to understand the party arena. Although Bobbio's perspective refers to Italy, one may use his ideas for other party arenas as well. His work is important because he concentrates on the definition of what is left and right, and due to the multiple perspectives that he offers at the same time, he enables a more profound and complex understanding of the concept.

Bobbio (1995) sees the left-right diapason in at least three different ways. First, he understands the left to right continuum as a banded one, where the left extreme meets the right extreme as one pole and where the opposite pole is the middle (centre), which can be understood as a lack of extremism. This interpretation is relatively close to another idea: that each extreme already includes initial characteristics of its opposition (yin-yang), and that one side cannot exist without its opposite pole (Bobbio, 1995, p. 83). The second interpretation might be that there is a continuum divided in half by the centre as a cleavage that separates left from right. However, Bobbio (1995) is open to the possibility that the centre is not a cleavage that necessarily separates, but an intermediate position between two sides of a continuum. In these conditions, the first part around the centre to the left and right is understood as a field of modesty where the involved actors are still achieving their goals by negotiation. Further on the continuum, there are both extremes for which a tendency towards activity/action is characteristic. The third interpretation of Bobbio (1995) is that the centre is everything that cannot be de- 
DRUŠ. ISTRAŽ. ZAGREB GOD. 23 (2014), BR. 2 STR. 349-368

PINTERIČ, U. ŽÚBOROVÁ, $V$ : PARTY ARENAS. scribed as extreme. From this perspective, one can assume that there is not and cannot be only one understanding of the party arena and that its de facto shape can be influenced by the real political situation in a certain state.

Bobbio (1995, p. 61) warns against electoral systems based on the majority vote, due to increasing the possibility of excluding a number of parties and creating artificial divisions between the left and right block, which might occur due to the fact that fewer parties will automatically be labelled as left and right (as it is the case in the U.S., despite both parties being understood as right if systematized in some CEE countries).

From the content point of view, Bobbio is addressing different issues, such as private property (1995, pp. 107-113), relation towards religion (1995, p. 78), relation between tradition and emancipation (1995, p. 78), etc. However, it seems that we are able to follow two main things from the content perspective. First, Bobbio argues that left and right are and shall always be defined within certain political contexts (1995, p. 80) and that the positivism of left and right is self-defined by members of a certain group (1995, p. 69). This means that it is highly impossible to get neutral assessment on political programmes. As Jonathan White notes: "Left and Right can be used to position opponents as similar or identical to a generally disliked third party, intentionally overlooking the differences which may exist between them so as to discredit one by association with another: consider the efforts made to discredit social democrats during the Cold War by associating them with Soviet communism" (White, 2010, p. 10; see also Harré \& Langenhove, 1992, p. 398).

It seems that one can only recognise the second scenario with a continuum and the centre as an intermediate area, which takes only the middle part of the continuum. However, we are able to observe the situation where the majority of political parties are usually very keen on interpretations that the centre is everything that cannot be considered extreme. Secondly, according to the issues that Bobbio (1995) is addressing, we can divide them into two main spheres. One sees, on the one hand, the economic issues and on the other hand, the social and political ones. It is important to remember that certain issues can be addressed as a domain of both spheres (e.g. economic and political liberalism).

\section{METHODOLOGICAL FRAMEWORK}

The methodology of comparative research is based on Bobbio's definition of political space, which is an elaborate political continuum (1995). Despite the fact that one may be able to split the political dimension into two: a political dimension and a social one, we acknowledge the 2-dimensional model 
DRUŠ. ISTRAŽ. ZAGREB GOD. 23 (2014), BR. 2, STR. 349-368

PINTERIČ, U.,

ŽÚBOROVÁ, $V$.

PARTY ARENAS...

(1) TABLE 1

Main features of the political space (Pinterič 2009, p. 162)

\begin{tabular}{lll}
\hline & Left & Right \\
\hline Economic side & State interventionism & Free market \\
& More taxes & Less taxes \\
& State social security & Social security on market basis \\
& Economic sustainability & Exploitation of raw resources \\
& Environment protection first & Economic expansion first \\
& Prosperity equality of workers & Equality of opportunities for individ- \\
& & uals to reach prosperity \\
Political side & Secularism & Religiosity \\
& Responsibility of the authorities & Respect of authorities \\
& Liberties of individual & Rights of the community \\
& Equality of citizens & Equality of opportunities for citizens \\
& Pro-choice & Pro-life \\
& Respect of changes & Respect of tradition \\
& Multiculturalism & National pride
\end{tabular}

of political space. Not considering that the idea of dimension is not to be strictly limited to one or the other side, we are able to define extremes on the basis of what might be exponential extremism. Some other authors (Kriesi et al., 2006) create political space across the economic and cultural (instead of the economic and political) dimensions.

In order to do so, we need to define the "content" party groups as left/right. If we agree with different authors (Riishøj, 2009), we can say that right wing political parties are traditionalist/conservative/nationalist. On the other hand, left wing so be understood as the mass media perception of the political continuum. ${ }^{1}$ Some specific cases might emerge - such as whether it is right to talk about Christian-democratic parties as a specific party group. In Europe it most certainly is. But if in Europe Islamic parties emerge, they will usually be denominated as "other". Maybe a more general label of "religious parties" would better describe both cases. More and more issue-oriented or narrow-oriented parties are emerging, and they are also labelled as "other". However, it seems that the "other" group cannot be spread on the political continuum, but more likely would find its place in the political space, because this positioning demands the assessment of political programme and not only coalition work. political parties might be socialist/liberal/green. This might al-

In the operationalization, we state that we are able to define four groups of characteristics that describe four sides of two continuums. We assume that those political parties that are centre-oriented will have less clearly expressed positions on issues that might be connected to the left-right continuum or they will have non-consistent political orientations on different issues. Centric positioning cannot be a product of the left political and right economic extremes or vice versa. 
DRUŠ. ISTRAŽ. ZAGREB GOD. 23 (2014), BR. 2 STR. $349-368$

PINTERIČ, U., ŽÚBOROVÁ, V. PARTY ARENAS.

$\rightarrow$ TABLE 2

Structure of the analysed articles number of articles taken into consideration)
On the basis of the labels for positioning used in the main national daily newspapers (web edition), we have created a political continuum and placed the parties in an approximate position, which is to be supported by expressions used in newspapers. In the Slovenian case, this part of the analysis is based on the newspapers Delo, Dnevnik and Večer issued in May 2011, while in the Slovak case, we used newspapers Sme, Pravda and Hospodárske noviny within the same period (see Table 2).

\begin{tabular}{lccc}
\hline Slovenia & Delo & Dnevnik & Večer \\
& 3 & 1 & 1 \\
Slovakia & Sme & Pravda & Hospodárske noviny \\
& 6 & 4 & 1 \\
\hline
\end{tabular}

We searched the political programmes of the parties and based on the indicators presented above, we placed the individual political parties into the political space. Within each programme we searched for the elements that can be placed within the political or economic dimension, according to Table 1 . In the next step, we summed up the difference which enabled us to simply position the party towards the left or the right within each dimension. The analysis was conducted on the basis of the political programmes of those political parties that were available online in June 2011. We need to stress that the party arena is constantly changing (in Slovenia new influential parties have emerged afterwards, in both countries early elections took place within a year from May 2011, etc.). As a result, many political changes and shifts are not discussed in this paper.

The sample of political parties used for both analysed countries is composed of political parties that won seats in the national parliaments of the respective countries in at least one of the last two legislative terms. For the Slovenian case, we took into account the 2004-2008 and 2008-2012 (which, due to political turbulences ended in autumn 2011) legislative terms and for the Slovak case, the 2006-2010, 2010-2014 (which also ended, due to political turbulences in autumn 2011). Table 3 shows the parties that fulfil the afore-mentioned criteria.

In the Slovenian case, two representatives of the Italian and Hungarian minorities are not taken into consideration, this is because they are not running on "political", but "minority" principles. In both legislative terms for the Slovenian National Assembly, seven political parties were present with the following general changes. The Christian-Democratic Party (NSi) lost its position in parliament, the new party Zares was created, mainly through reconstruction of the LDS and SD, 
and entered parliament. SLS joined the Slovenian Youth Party and together emerged as SLS+SMS at the 2008 elections. In

(1) TABLE 3

List of analysed parties in Slovenia and Slovakia general, we can say that based on party family criteria, there were four left-wing and four right-wing parties that were in parliament.

\begin{tabular}{|c|c|c|c|c|c|}
\hline $\begin{array}{l}\text { Slovenia } \\
\text { Name (Abbreviation) }\end{array}$ & Term(s) & Party family & $\begin{array}{l}\text { Slovakia } \\
\text { Name (Abbreviation) }\end{array}$ & Term(s) & Party family \\
\hline $\begin{array}{l}\text { Slovenska } \\
\text { demokratska stranka } \\
\text { (SDS) }\end{array}$ & $\begin{array}{l}2004-2008 \\
2008-2012\end{array}$ & Conservative & $\begin{array}{l}\text { Slovenská krest’ansko- } \\
\text {-demokratická únia } \\
\text { (SDKÚ-DS) }\end{array}$ & $\begin{array}{l}2006-2010 \\
2010-2014\end{array}$ & $\begin{array}{l}\text { Liberal- } \\
\text {-conservative }\end{array}$ \\
\hline $\begin{array}{l}\text { Liberalna } \\
\text { demokracija } \\
\text { Slovenije (LDS) }\end{array}$ & $\begin{array}{l}2004-2008 \\
2008-2012\end{array}$ & Liberal & $\begin{array}{l}\text { Krest'ansko- } \\
\text {-demokratické hnutie }\end{array}$ & $\begin{array}{l}2006-2010 \\
2010-2014\end{array}$ & $\begin{array}{l}\text { Christian- } \\
\text {-democratic }\end{array}$ \\
\hline $\begin{array}{l}\text { Združena lista } \\
\text { socialnih } \\
\text { demokratov/Socialni } \\
\text { demokrati (SD) }\end{array}$ & $\begin{array}{l}2004-2008 \\
2008-2012\end{array}$ & Socialist & $\begin{array}{l}\text { Smer-sociálna } \\
\text { demokracia } \\
\text { (Smer-SD) }\end{array}$ & $\begin{array}{l}2006-2010 \\
2010-2014\end{array}$ & Socialist \\
\hline $\begin{array}{l}\text { Nova Slovenija- } \\
\text {-krščanska ljudska } \\
\text { stranka (NSi) }\end{array}$ & $2004-2008$ & Christian-democratic & $\begin{array}{l}\text { L'udová strana- } \\
\text {-Hnutie za } \\
\text { demokratické } \\
\text { Slovensko } \\
\text { ('LS-HZDS) }\end{array}$ & $2006-2010$ & People's party \\
\hline $\begin{array}{l}\text { Slovenska ljudska } \\
\text { stranka/SLS+SMS } \\
\text { (SLS) }\end{array}$ & $\begin{array}{l}2004-2008 \\
2008-2012\end{array}$ & People's party & $\begin{array}{l}\text { Strana mad'arskej } \\
\text { koalície (SMK) }\end{array}$ & $2006-2010$ & Conservative \\
\hline $\begin{array}{l}\text { Slovenska } \\
\text { nacionalna stranka } \\
\text { (SNS) }\end{array}$ & $\begin{array}{l}2004-2008 \\
2008-2012\end{array}$ & Nationalist & $\begin{array}{l}\text { Slovenská národná } \\
\text { strana }\end{array}$ & $\begin{array}{l}2006-2010 \\
2010-2014\end{array}$ & Nationalist \\
\hline $\begin{array}{l}\text { Demokratična stranka } \\
\text { upokojencev } \\
\text { Slovenije (DeSUS) }\end{array}$ & $\begin{array}{l}2004-2008 \\
2008-2012\end{array}$ & Other (pensioner) & $\begin{array}{l}\text { Most-Híd } \\
\text { (Most-Híd) }\end{array}$ & 2010-2014 & Liberal \\
\hline Zares (Zares) & $2008-2012$ & Liberal & $\begin{array}{l}\text { Sloboda a Solidarita } \\
\text { (SaS) }\end{array}$ & 2010-2014 & Liberal \\
\hline
\end{tabular}

In Slovakia, six parties were present throughout both electoral periods. The Movement for Democratic Slovakia (LS-HZDS) lost their position in the parliament after the elections, which were held in June 2010. In 2009 the new liberal party called Freedom and Solidarity (SaS) was created and it won seats in the 2010 parliamentary elections. A part of the Hungarian coalition (SMK) lost its position in the parliament after the elections in 2010. Representatives of SMK alienated a new party called The Bridge (Most-Híd). The previously most powerful political party Direction-Social Democracy (Smer-SD) and the Slovak nationalist party (SNS) lost some of their seats in the parliament and their governing positions as well. After the elections in June 2010 the government consisted of four political parties, Slovak Democratic and Christian Union-Democratic Party (SDKÚ-DS), The Movement of Christian Democrats $(\mathrm{KDH})$ and the new parties Sas, Most-Híd. 
DRUŠ. ISTRAŽ. ZAGREB GOD. 23 (2014), BR. 2 STR. 349-368

PINTERIČ, U. ŽÚBOROVÁ, $V$. ZUUBOROVA, V.:
One should be aware that the political parties in both countries analysed were developing, so this analysis is valid only for the situation as it occurred in May 2011, and based upon the party programmes (from June 2011) of those political parties that were in parliament during one of the last two terms (between 2004 and 2014). This means that some political parties were left out (those that were in parliament before $2004 / 2006$ or after 2011). At the same time, we are aware that some parties changed only their name. We use the name under which they were active at the time when the analysis was conducted. If some political party was disbanded, we did not take it into consideration, because we assumed that there was no political descendant of such a party. Due to these reasons, the research might be understood as blind-ended and not fully reliable to those who specialize in political parties.

\section{RESEARCH RESULTS}

The media systematically refer to different parties as left or right on the basis of the simple principle of party behaviour/ origin $^{2}$ which implies Bobbio's (1995, p. 62) logic of placing political parties in groups based on the credo "The friend of my enemy is my enemy as well". This over-simplification tells us a lot about the media's understanding of party politics that seems to be obviously based not on the content, but on the connections between parties. However, there is no reason not to believe the result of Newton's research (2006, p. 226), which states that more politically burdened media are less trusted in political issues and have a lower influence level on the general population of readers. This implies that, at least in the case of Slovenia, there should be some scepticism about how Delo marked certain parties (due to the disputed connection of the Delo newspaper to left wing parties). According to our methodology, we are able to indicate a media presentation of the Slovenian political parties that were in parliament at least in one of two most recent mandates, as follows from Table 4.

$\rightarrow$ TABLE 4

Media unidimensional presentation of the

Slovenian political

parties on the political continuum in May 2011

\begin{tabular}{ccccc}
\hline SD, LDS, Zares & DeSUS & & SLS & SDS, NSi, SNS \\
\hline $\begin{array}{c}-2 \\
\text { Left }\end{array}$ & $\begin{array}{c}-1 \\
\text { Centre-left }\end{array}$ & $\begin{array}{c}0 \\
\text { Centre }\end{array}$ & $\begin{array}{c}\text { Centre-right } \\
\text { Right }\end{array}$ & $\begin{array}{c}2 \\
\text { Rignt }\end{array}$ \\
\hline
\end{tabular}

Table 4 is based on quotes in the e-versions of Delo, Dnevnik and Večer newspapers such as: "levi trojček": "Left triple" that marks the 2008-2012 ruling coalition of SD, LDS and Zares. (http://www.delo.si/novice/politika/novi-stari-predsednikpodmladka-sd-je-marko-kastelic.html)

The president of SD mentioned that "their" (SD) competition is on the left wing as well. (http://www.delo.si/novice/ politika/desus-danes-dokoncno-o-izstopu-iz-koalicije.html) 
DRUŠ. ISTRAŽ. ZAGREB GOD. 23 (2014), BR. 2, STR. 349-368

PINTERIČ, U

ŽÚBOROVÁ, $V$ :

PARTY ARENAS...
O TABLE 5

Media unidimensional presentation of Slovak political parties on the political continuum in May 2011
As shown in Table 4, media representation of political parties in Slovenia imposes that the centre of the political continuum is empty and that extreme polarisation is present. The media in Slovenia are mainly emptying the centre position on the left-right scale by stating that there is the so-called "Left triple" composed of SD, LDS and Zares. On the other hand, there is the "Spring triple", marking the three right parties (SDS, NSi and SLS) and their progenitors that were playing an important role in the "Slovenian spring" (independence from Yugoslavia). Next to this on the right side is also SNS, due to its nationalistic identification. In the analysed period, one can observe that none of the analysed newspapers in the given period were systematically using "right/left" labels for certain parties or party groups (they usually referred to party names or more government/opposition denomination). From this perspective, one can argue that media in general refuse to use left/right polarization, which is more common in statements of politicians.

\begin{tabular}{ccccc}
\hline Smer-SD & Smer-SD* & L'S-HZDS & $\begin{array}{c}\text { SDKÚ-DS, } \\
\text { KDH, SaS, } \\
\text { Most-Híd** }\end{array}$ & $\begin{array}{c}\text { SDKÚ-DS, KDH, } \\
\text { SaS, Most-Híd, } \\
\text { SMK, SNS }\end{array}$ \\
\hline $\begin{array}{c}\text { Left } \\
\text { Centre-left }\end{array}$ & $\begin{array}{c}0 \\
\text { Centre }\end{array}$ & $\begin{array}{c}1 \\
\text { Centre-right }\end{array}$ & $\begin{array}{c}2 \\
\text { Right }\end{array}$ \\
\hline
\end{tabular}

Table 5 is based on quotes in the e-versions of newspapers Sme, Pravda and Hospodárske noviny such as:

*"The left-wing Direction (Smer-SD)", the most powerful parliament and opposition party 2010-2014. (http://www.sme.sk/ c/5810761/zivnostnikov-drazdia-ich-strany.html)

**"The "RIGHT" is slowly catching up on Fico". In the article, SDKÚ-DS, KDH, Most-Híd and SaS were mentioned as centre-right wing parties. (http://spravy.pravda.sk/volby/clanok/243327pravica-sa-dotahuje-na-fica/)

In the case of Slovakia, one can see that media often refer to certain parties as right/centre-right or left/centre-left. Due to this, with the exception of three parties, they all occupy two different positions in Table 5.

\section{POLITICAL PROGRAMMES IN COMPARATIVE PERSPECTIVES}

We analysed the party programmes in June 2011 based on the political-economic left-right space. With regard to the political dimension, we consider as more left-orientated elements those that support individual freedoms, secularization and respect for citizens' personal preferences. The elements of the political right are connected with an absence of state intervention into individuals' rights, respect of authorities, and 
DRUŠ. ISTRAŽ. ZAGREB GOD. 23 (2014), BR. 2 STR. 349-368

PINTERIČ, U., ŽÚBOROVÁ, $V$. ZUUBOROVA, V.:

$\rightarrow$ FIGURE 1

Position of Slovenian parties based on political programmes traditions, importance of national identity, etc. The economic left is connected to sustainable development with an ecological dimension, strong protection of social rights, and state intervention into the economy in order to protect the interests of workers and consumers. The economic right is presented by a belief in the free market (minimal state), sustainable development on the basis of economic sustainability, protection of capital opportunities, and state interventionism into economy in order to protect the interests of enterprises.

For each analysed party, political and economic policy options in the party programme are counted. For each category, the difference between the numbers of those statements was calculated and adjusted as a ratio that gives us the position in the figures below for political and economic dimensions.

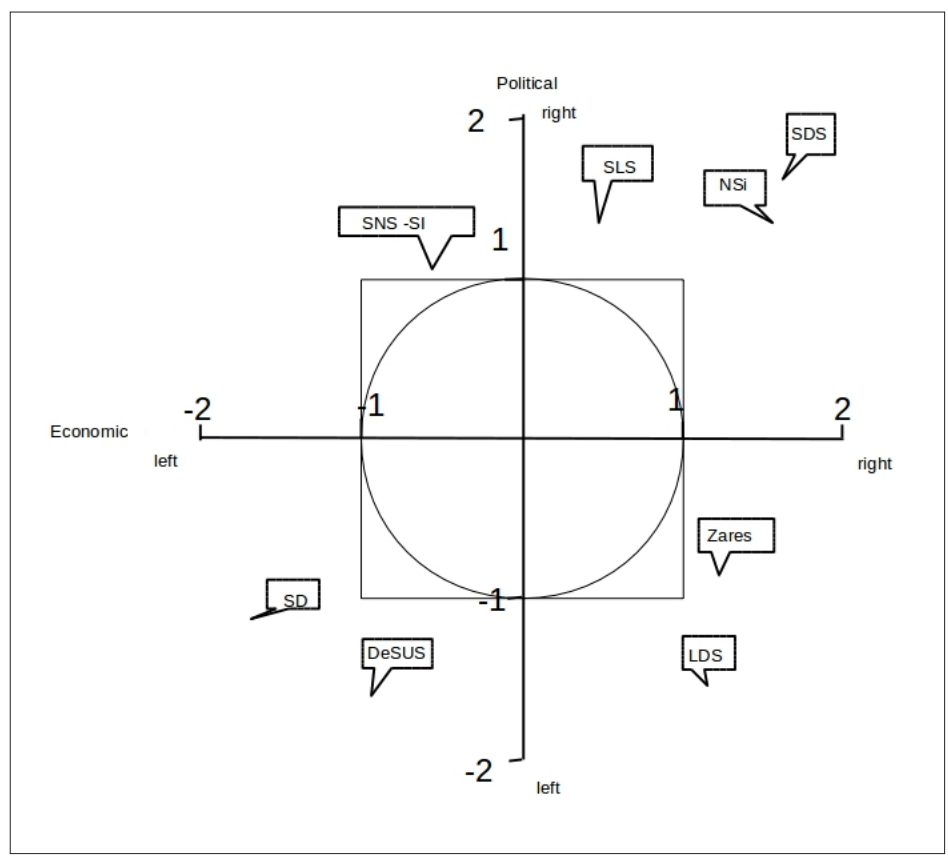

Figure 1 shows that the majority of Slovenian political parties provide much greater diversity on different issues and they are often not even partly connected to the journalist classification. The most obvious discrepancy is connected to the SNS, which is publicly labelled as the classical right-wing nationalist party, but from the economic point of view, it seems closer to the left-centre than to the right. The second important difference between media presentation and programmes of the Slovenian political parties is seen in the cases of LDS and Zares. These parties have a relatively strong right economic orientation, despite being publicly labelled as left-wing. The most extreme party from the economic point of view is 
DRUŠ. ISTRAŽ. ZAGREB GOD. 23 (2014), BR. 2, STR. 349-368

PINTERIČ, U.

ŽÚBOROVÁ, V.

PARTY ARENAS...

$\rightarrow$ FIGURE 2

Position of Slovak parties based on political programmes
SD (with only a marginal difference with regard to SDS and a different direction). SDS is at the same time the most right-orientated party, politically and economically, a fact consistent with the conservative/capitalist orientation of the party. The left pole of the space is much more diverse. As previously mentioned, SD is the most extreme party in economic terms, while DeSUS is the most extreme from the political point of view. LDS and Zares can be seen as economically reformed socialist parties, developed into cadre parities, with strong support from the private sector. According to their political programmes, Zares and SNS are the most moderate political parties. Despite the fact that the majority of the Slovenian political parties are avoiding certain ideological topics, it is still possible to define their basic characteristics.

Figure 2 shows that the majority of the Slovak political parties are more or less centred along the right-political line (a conclusion that applies particularly to the stable political parties, like SDKÚ-DS, KDH or Smer-SD) and also that they are far from being clearly polarized between left and right. In general, we can observe that the stable political parties with the expectation of the SNS are not providing diversity in specific or common issues.

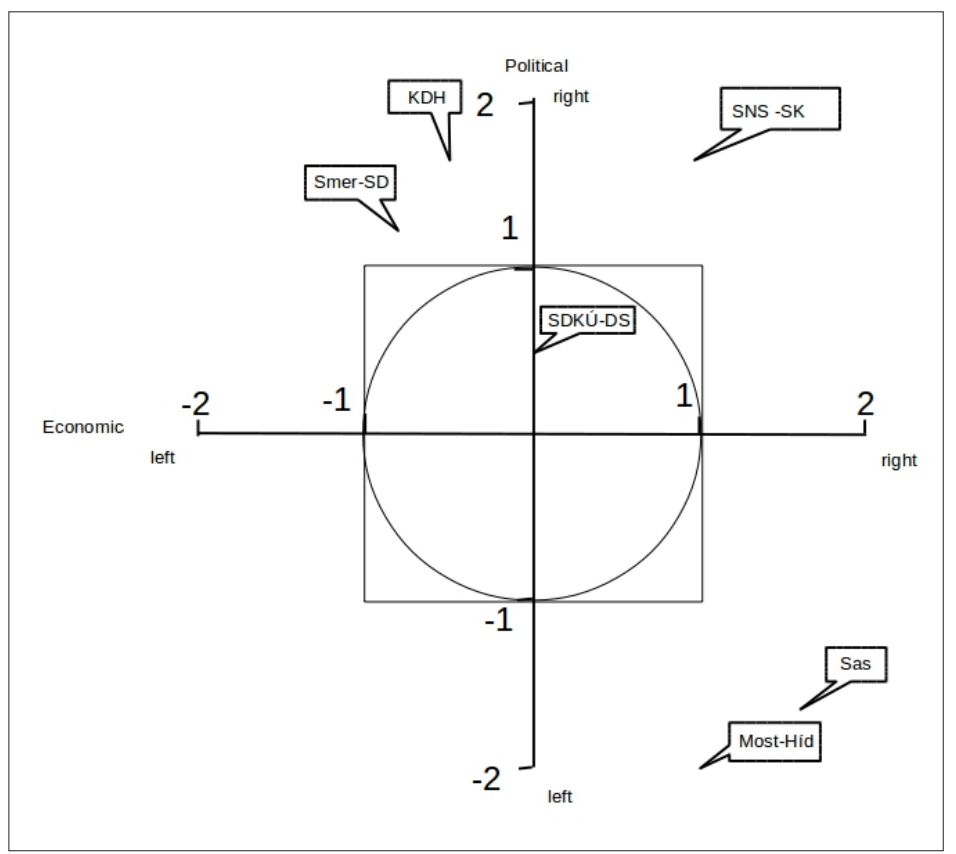

Most obvious is the fact that they are only partly connected to journalistic classification. The next difference, between media presentation and the programmes of Slovak political parties is the case of the liberal political parties - SaS and 
DRUŠ. ISTRAŽ. ZAGREB GOD. 23 (2014), BR. 2 STR. 349-368

PINTERIČ, U. ŽÚBOROVÁ $V$. ZUBOROVA, V.:
Most-Híd - that were presented as parts of the whole right-wing coalition. According to the analysed party programmes, both political parties are economically right-wing parties, but politically they are much closer to the extreme left, due to strong programme openness to ideas such as the equality of citizens and multiculturalism, including the topic "pro-choice", promoting the identity of each ethnic minority in Slovakia, developing their educational system, their cultural and social institutions." (see Internet 1). They also call for equality of citizens, including equality of women, Roma citizens, etc. As regards the political programme, politically and economically (as it is presented as "Nationalist"), SNS seems to be the most extreme right-wing party.

The next most important difference between the media presentation and the programme of the political party can be seen in the case of $\mathrm{KDH}$. It is traditionally presented as a conservative political party with Christian values, but its position in the economic dimension is more towards the left-centre due to strong state social security and its manifesto presents the same "social" patterns as the party manifesto of Smer-SD. For example, both parties are against "more taxes", but they are calling for "luxury taxes", which would, from the perspective of $\mathrm{KDH}$, apply to the consumption of luxury goods and higher taxes on gambling. At the same time, $\mathrm{KDH}$ is politically the second most right-oriented political party (after SNS). With regard to the economic dimension, closest to the Christian-democratic $\mathrm{KDH}$ is Smer-SD, which officially belongs to the group of socialist parties and can be seen more as an exemption in its economic orientation. When the political party Smer-SD was formed, it had the tendencies to be viewed as a left-centrist political subject. Also, after the incorporation of the small left-wing parties, as Muránsky notes, the period of political absorption (Muránsky, 2004, p. 9), the party still remains, or, more precisely, it still promotes itself in the media as a left-wing political party with a sense of social democracy. But with a deeper look at their political and economic dimensions, we can see clear differences. For example, Smer-SD used a strong leftist rhetoric with the promotion of social benefits (for example, to keep the social benefits that were implemented in their electoral period). In the economic dimension, the Smer-SD promotes a pragmatic view for the economic and social policies in its party manifesto and also a successfully oriented policy away from any ideological colouring (Žúborová, 2010, pp. 134-135). In our research, the most centre-oriented political party in Slovakia was SDKÚ (it is economically and politically the most "purely" centre-oriented one). However, with a change of party leadership in 2012, the party received a more profiled position. Political programmes of L'S-HZDS and SMK were not available to the public at that time. 


\section{COMPARATIVE PERSPECTIVE}

Joining both graphical presentations together gives us a picture of how political parties in both countries correspond with each other. In the comparative perspective, we can observe that economic liberalism has not been automatically followed by political conservativism as in Western countries, but with a political liberalism, as in the cases of SaS, Most-Híd, or LDS, Zares.

An interesting comparative element can be seen in the position of two Christian-democratic parties in Slovakia and Slovenia, especially in the economic dimension, while politically they are relatively similar to one another. $\mathrm{KDH}$, as a Christian party in Slovakia, is in the economic dimension much closer to the left-centre than NSi. The next interesting case is the difference between the Slovak and Slovenian SNS. Slovak nationalists are a "pure" right-wing party politically as well as economically and are also seen as such by the media. But the Slovenian SNS is in its economic dimension much closer to the left-centre. Such a situation can be partly explained by the type of Slovenian nationalist party, which is more patriotic than nationalist. Patriotism can also be seen in the political programme of the Slovenian SNS through the intense state-dependent social care and health care policies as well as other forms of protecting the quality of life of their citizens.

COFURE 3
Comparative

positioning of Slovak and Slovenian political parties

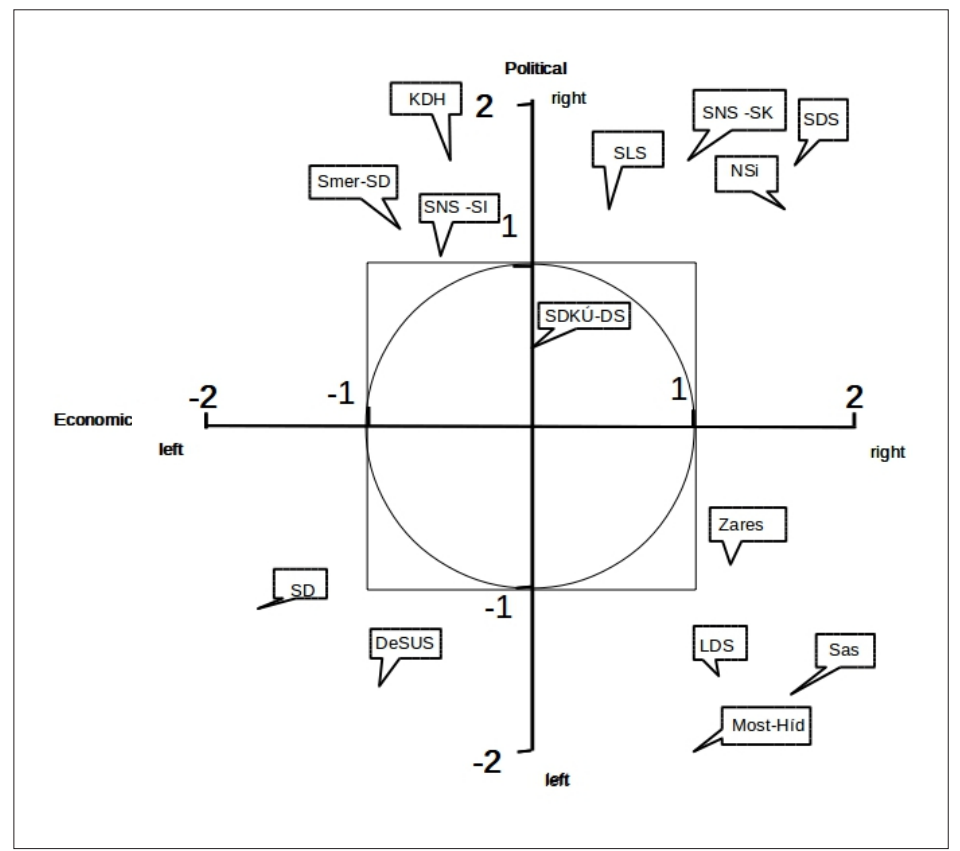

If we observe the socialists in both countries, we can also see the difference, this time not in the political but in the economic dimension. While the Slovenian socialists are "pure" left- 
DRUŠ. ISTRAŽ. ZAGREB GOD. 23 (2014), BR. 2 STR. $349-368$

PINTERIČ, U., ŽÚBOROVÁ, $V$. ZUBOROVA, V.: -wing in the political and economic sense, Slovak Smer-SD, is much closer in political dimension to the centre-right.

In general, we can say that the party systems in Slovakia and Slovenia are relatively strongly fragmented and polarized (slightly more in the case of Slovenia). However, some interesting cases, such as SDKÚ-DS, which was calling itself a liberal-conservative party (party manifesto SDKÚ-DS, 2010: 8) do exist.

Generally speaking, the conflict line of the left-right divide was not visible in the Slovak party system in the first stage of the transition period, but it developed after the elections in 1998 and 2002, "when the political conflict began to take shape based on the socio-economic cleavages along the left-right axis" (Gýarfášová \& Krivý, 2007, p. 83). After the elections in 2006 , this division, especially the economic dimension of it, was clearly visible and crucial for the increase of electoral preference of the political party Smer-SD. The latter was promoted in the media, as a left-wing subject and the most crucial and relevant competitor of the right-wing "conglomerate".

If we consider that parties like KDH, SDKU-DS, SaS and Most-Híd were in the period 2010 - 2012 governmental parties, we can allege a high polarization in the economic and political dimensions (which can be understood also as a government of national unification). This specific partnership runs parallel to all dimensions - starting from the left-wing economic dimension represented by $\mathrm{KDH}$, through the centre-oriented SDKÚ under Iveta Radičová, through the right-wing economic dimension presented by SaS and Most-Híd. We can also observe that the manifesto and also the electoral programme is highly dependent on the party leader, which we can see for example in the position of SDKÚ-DS under Iveta Radičová, and then Pavol Frešo, which switched position from a centre-oriented to a right-wing oriented party. In the Slovenian case, it is difficult to understand the political or economic separation between left and right as strongly relevant. The main cleavage occurs in the relation towards the communist period, with some exceptions such as SLS joining governing coalitions of "left-wing" parties (SD, LDS, DeSUS). The economic crisis is supporting the idea of creating a broad coalition, however, so far there has been no political willingness to overcome ideological differences and join for future development.

We have to mention that the Slovenian and Slovak political parties not only differ in the comparative view according to Bobbio's theory, but also from the European perspective. As Hloušek and Kopeček (2010) state, both "Christian-democratic" parties in Slovenia (NSi, SLS) are more or less in favour of the programme priorities that are consistent with the EPP, as it is in the case of the "new" SDKÚ-DS party under Pavol 
DRUŠ. ISTRAŽ. ZAGREB GOD. 23 (2014), BR. 2, STR. 349-368

PINTERIČ, U., ŽÚBOROVÁ, V.: PARTY ARENAS...
Frešo. On the other hand, Slovak KDH does not coincide with the position when compared to the EU party structure as well as its position in the international arena. Another example of a comparable party programme priority is the fact that both liberal parties in Slovenia (LDS, Zares) agree at the European level and belong within the institutional framework of the ELDR (Hloušek \& Kopeček, 2010, pp. 149-151).

Such a blurred and complicated situation can probably be easily explained by something that was initially connected to the party situation in Slovakia in 1990 and was described as a lack of professionalism, lack of sufficient ideological profiling and frequent internal disintegrative processes (Klimovský, 2008, p. 47). On this basis one can argue that in the last 10-20 years there was no significant change. There is still a lack of professionalism; this time not in the sense of having a stable, professional institutional structure, but in the sense of a lack of political culture, responsibility and too much party-centrism in relation to public interest. Ideological profiling was strengthened during this time, but usually over political controversies rather than key development issues. And finally, there is still a high level of party-arena instability, caused by emerging new parties, disintegrations of existing parties, the merging of different party fractions, etc. Such dynamics cause constant movement of political parties, searching for their position in the political space in the sense of adjusting their ideology and catching the highest possible electoral result.

\section{CONCLUSIONS AND DISCUSSION}

$\longrightarrow$ As it was shown in the short media analysis provided above, it is evident that mass media make relatively strict distinctions between left and right parties. However, it seems that this difference is based mainly on the ideological connection to the communist party in the pre-democratic period. In the case of Slovenia or Slovakia, we are not able to argue that parties are centre-oriented according to their political programmes. However, we were able to show that centre-oriented parties represent a construct that is sold by political parties in times of electoral campaigning. Slovak and Slovenian parties lean towards extremes in the political space. According to the analysed political programmes of political parties, we are able to argue that there are more right-oriented than left-oriented political parties and that Slovenia still has a clear left pole (parties oriented left in the economic and political dimensions), while this is not the case in Slovakia. On the other hand, we were able to observe that in Slovakia, there are more politically right-oriented parties than left ones, and more than in Slovenia. From this information, we can assume that Slovakia is politically (societally) more traditional than Slovenia. In the 
DRUŠ. ISTRAŽ. ZAGREB GOD. 23 (2014), BR. 2, STR. 349-368

PINTERIČ, U. ŽÚBOROVÁ, $V$. ZUBOROVA, $\mathrm{V}$.: economic dimension, we are able to observe the concentration of parties on the right side of the scale in both countries, indicating that both countries are embracing a capitalist approach in their economies (as opposed to the socialist economy and not necessarily as opposition of market economy vs. state-planned economy). According to the spatial spread of political parties within the political space in Slovenia and Slovakia, we are able to confirm that the Slovak parties are politically more right-oriented. In both cases, there were more parties analysed on the right side of the economic dimension.

The reason for that was that Slovenia, with a "moderate socialism", allowed a higher degree of freedom in the political and economic spheres and was able to keep at least two parties with a strong left orientation. Slovakia, on the other hand, with a stronger tradition of "communist repression" in the past left a limited space for "left-wing" parties. In other words, it is possible to argue that the continuity of "left-wing" parties in Slovenia is connected to a lower level of repression by the regime which was understood as "left-wing".

Lately, some authors (i.e. Prijon, 2012) have indicated that, at least in Slovenia, the general political and administrative elitism is de facto a more important factor of reality than the left-right orientation of politics. Therefore, further research will be focussed on the question of the party space being dominated by amorphous political-administrative elites with specific interests, whose image of political differences and their struggle represent no more than a cover up. Thus political actions/appearances will be compared to the advocated/accepted policy solutions in different fields.

\section{NOTES}

${ }^{1}$ It shall be noted, that mass media (as well as the public), simplify the left-right polarization and do not develop the full extent of political space. Thus they consider also economic topics as elements of political polarization.

2 The left and right denominations generally emerged from the cleavage of being formerly communist or anti-communist. Thus, left-wing parties have historically stronger ties to the communist party before the democratization process started.

\section{REFERENCES}

Blumler, J. G., \& Kavanagh, D. (1999). The third age of political communication: Influences and features. Political Communication, 16(3), 209-230. doi:10.1080/105846099198596

Bobbio, N. (1995). Desnica in levica [Right and left]. Ljubljana: Znanstveno in publicistično središče.

Daalder, H. (1992). A Crisis of Party? Scandinavian Political Studies, 15(4), 269-286. doi:10.1111/j.1467-9477.1992.tb00022.x 
DRUŠ. ISTRAŽ. ZAGREB GOD. 23 (2014), BR. 2, STR. $349-368$

PINTERIČ, U. ŽÚBOROVÁ, $V$ PARTY ARENAS...
DeSuS danes dokonco o izstopu iz koalicije (May 2011). Delo. Available at http://www.delo.si/novice/politika/desus-danes-dokoncno-oizstopu-iz-koalicije.html

Fink Hafner, D. (2001). Politične stranke [Political parties]. Ljubljana: Fakulteta za družbene vede.

Generálna línia SDKÚ-DS na roky 2010 - 2014, Sloboda a zodpovednost', poriadok a spravodlivost' (2010). SDKÚ-DS. Available at http://www. sdku-ds.sk/data/MediaLibrary/911/generalna-linia-2010.pdf

Gyárfásová, O., \& Krivý, V. (2007). Electoral behaviour: Persistent volatility or clear sign of consolidation? Case of Slovakia. In V. Hlousek, \& R. Chytilek (Eds.), Parliamentary elections and party landscape in the Visegrad Group countries (pp. 79-106). Brno: Democracy and Culture Study Center.

Harré, R., \& Van Langenhove, L. (1992). Varieties of positioning. Journal for the Theory of Social Behaviour, 21(4), 393-407. doi:10.1111/ j.1468-5914.1991.tb00203.xx

Hloušek, V., \& Kopeček, L. (2010). Politické strany, Puvod, ideologie a transformace politických stran v západní a střední Evropě [Political parties, origin, ideology and transformation of political parties in Western and Central Europe]. Praha: Grada.

Internet 1: http://www.most-hid.sk/sk/content/schvaleny-programstrany-most-hid

Kitschelt, H. (1992). The formation of party systems in East Central Europe. Politics \& Society, 20(1), 7-50. doi:10.1177/0032329292020001003 Klimovský, D. (2008). Politics and its impact on the reform processes: The case of public administration reform in Slovakia (1989-2006). In J. Musil (Ed.), Space and historical time as dimensions of social change (pp. 45-64). Praha: Charles University.

Kriesi, H., Grande, E., Lachat, R., Dolezal, M., Bornschier, S., \& Frey, T. (2006). Globalization and the transformation of the national political space: Six European countries compared. European Journal of Political Research, 45(6), 921-956. doi:10.1111/j.1475-6765.2006.00644.x

Konkurzy nie sú pre Bratislavu (May 2011). SME. Available at http:// bratislava.sme.sk/c/5900190/konkurzy-nie-su-pre-bratislavu.html\# ixzz1NZ5IDfFL

Kopecký, P. (1995). Developing party organization in East-Central Europe. What type of party is likely to emerge? Party Politics, 1(4), 515-534. doi:10.1177/1354068895001004005

Koprivnik, S. (2001). Vsebina ideološkega kontinuuma levo-desno v Sloveniji v preteklem desetletju [The content of the ideological left-right continuum in Slovenia in the past decade]. In D. Fink-Hafner, \& M. Haček (Eds.), Demokratični prehodi II [Democratic transitions II] (pp. 138-170). Ljubljana: FDV.

Lewis, P. G. (1994). Central Europe since 1945. London: Longman.

Lewis, P. G. (2007). Political parties. In S. White, J. Batt, \& P. G. Lewis (Eds.), Developments in Central and East European politics 4 (pp. 174-192). Hampshire: Palgrave Macmillan.

Mair, P. (1996). What is the different about post-communist party systems? Glasgow: University of Strathclyde. 
DRUŠ. ISTRAŽ. ZAGREB GOD. 23 (2014), BR. 2 STR. 349-368

PINTERIČ, U., ŽÚBOROVÁ, $V$.: ZUBOROVA, $\mathrm{V}$.:
Muránsky, M. (2004). Die Marginalisierung der Linken in Parteienlandschaft der Slowakei. Politische Analysen, 4, 1-12. Berlin: Friedrich Ebert-Stiftung. Available at http://library.fes.de/pdf-files/id/01937.pdf Newton, K. (2006). May the weak force be with you: The power of the mass media in modern politics. European Journal of Political Research, 45(2), 209-234. doi:10.1111/j.1475-6765.2006.00296.x

Novi stari presednik podmladka SD je Marko Kastelic (May 2011). Delo. Available at: http://www.delo.si/novice/politika/novi-stari-predsednikpodmladka-sd-je-marko-kastelic.html

Pinterič, U. (2009). Črna skrinjica političnih sistemov [Black box of political systems]. Ljubljana: Vega Press.

Pop-Eleches, G., \& Tucker, J. A. (2010). After the party: Legacies and left-right distinctions in post-communist countries. Presentation at the 2010 Annual Meeting of American Political Association, Washington. Available at http://www.princeton.edu/čgpop/LR\%20Legacies\%20GPE \%20JAT\% 20APSA \% 202010.pdf

Prijon, L. (2012). Clientelism and Slovenian public administration reform. Polish Sociological Review, 4(180), 545-560.

Profily kandidujúcich politických strán, Smer HZDS, SDKÚ, KDH, SMK, SNS, SF, KSS (May 2011). SME. Available at http://volby.sme.sk/ c/2767492/profily-kandidujucich-politickych-stransmerhzds-sdku kdhsmksnssfkss.html

Riishøj, S. (2009). Transition, consolidation and development of parties and party systems in Central Europe 1989-2009: Poland, the Czech Republic, Slovakia and Hungary. Ondese: University of Southern Denmark.

Sartori, G. (2005). Strany a Stranícke systémy [Parties and party systems]. Brno: CKD.

Sčítanie sú vyhodené peniaze, tvrdí SNS (May 2011). SME. Available at http://www.sme.sk/c/5937693/scitanie-su-vyhodene-peniaze-tvrdisns.html

Slota sa urazil na národný Smer (May 2011). SME. Available at http:// www.sme.sk/c/5832691/slota-sa-urazil-na-narodny-smer.html

SNS začne zverejňovat' monitoring mad’arských médií (May 2011). SME. Available at http://www.sme.sk/c/5934471/sns-zacne-zverejnovatmonitoring-madarskych-medii.html

Tavits, M., \& Letki, N. (2009). When left is right: Party ideology and policy in post-communist Europe. American Political Science Review, 103(4), 555-569. doi:10.1017/S0003055409990220

Večerník, J. (1999). Střední vrstva v české transformace [The middle classes in the Czech reforms]. Sociologický časopis, 35(1), 33-52. Available at http://sreview.soc.cas.cz/uploads/0a7d7f41ca6544a78359a66a 7fe358c4c7bcb0ec_215_033VECER.pdf

Yordanova, N., \& Zhelyazkova, A. (2011). Reversed economic left-right party ideology? Transposition of EU legislation in Eastern vs. Western Europe. Presented at the EUSA 12 Biennial International Conference, Boston Available at http://euce.org/eusa/2011/papers/3h_yordanova. pdf 
DRUŠ. ISTRAŽ. ZAGREB GOD. 23 (2014), BR. 2, STR. $349-368$

PINTERIČ, U

ŽÚBOROVÁ, $V$

PARTY ARENAS...
White, J. (2010). Left, right and beyond: The pragmatics of political mapping. London School of Economics and Political Science (LSE) EQS Paper No. 24. Available at SSRN: doi:10.2139/ssrn.1624805

Wojtas, K. (2006). The "marketing party" as a model for the development of contemporary political parties. Central European Political Studies Review, 8(2-3), 187-224. Available at http://www.cepsr.com/dwnld/ wojt4.pdf

Wyman, M., White, S., Milier, B., \& Heywood, P. (1998). The place of party in post-communist Europe. In P. Norris (Ed.), Elections and voting new challenges, new perspectives (pp. 535-548). Dartmouth: Ashgate.

Živnostníkov dráždia ich strany (May 2011). SME. Available at http:// www.sme.sk/c/5810761/zivnostnikov-drazdia-ich-strany.html

Žúborová, V. (2010). Hl'adanie stability na l'avom brehu [Searching for stability on the left strand]. In J. Bureš, J. Charvát, \& P. Just (Eds.), Levice v České republice a na Slovensku 1989 - 2009 [The Left in Czech and Slovak Republic 1989-2009] (pp. 127-136). Plzeň: Aleš Čeněk.

\section{Stranačke arene u Sloveniii i Slovačkoi}

Uroš PINTERIČ, Viera ŽÚBOROVÁ

Fakultet društvenih znanosti, Trnava, Slovačka

Članak počiva na komparativnom istraživanju položaja političkih stranaka na tzv. "kontinuumu lijevo-desno", kako to određuju mediji, nasuprot njihovu položaju na istom kontinuumu, kako je utvrđeno stranačkim programima. Autori tvrde da je medijsko određivanje lijevoga ili desnoga položaja stranke s vremenom dovelo do otklanjanja lijevo/desnih atributa iz političkih programa. U članku se upozorava na to da u Sloveniji i Slovačkoi postoji razlika između položaja u koje stranke smještaju mediji i pozicioniranja stranaka na temelju njihovih stranačkih programa.

Ključne riječi: lijevo, desno, političke stranke, Slovenija, Slovačka, masovni mediii, politički programi 